$1-1-1976$

\title{
Some microbial, drying, and odor reduction studies of poultry wastes
}

Susan Hurst Calderone

H. A. Wilson

Follow this and additional works at: https://researchrepository.wvu.edu/ wv_agricultural_and_forestry_experiment_station_bulletins

\section{Digital Commons Citation}

Calderone, Susan Hurst and Wilson, H. A., "Some microbial, drying, and odor reduction studies of poultry wastes" (1976). West Virginia Agricultural and Forestry Experiment Station Bulletins. 646T.

https://researchrepository.wvu.edu/wv_agricultural_and_forestry_experiment_station_bulletins/720 @ WVU. It has been accepted for inclusion in West Virginia Agricultural and Forestry Experiment Station Bulletins by an authorized administrator of The Research Repository @ WVU. For more information, please contact ian.harmon@mail.wvu.edu. 


\title{
THE AUTHORS
}

Susan Hurst Calderone is a former graduate student in Plant Pathology and Harold A. Wilson is Bacteriologist Emeritus, West Virginia University Agricultural Experiment Station.

\section{ACKNOWLEDGMENTS}

This study was supported in part by Hatch 210-Disposal and Utilization of Manures from Poultry Cages and NE-63-Disposal and Utilization of Dairy and Poultry Wastes by Land Application.

\author{
West Virginia University \\ Agricultural Experiment Station \\ College of Agriculture and Forestry \\ Dale W. Zinn, Director \\ Morgantown
}




\section{Contents}

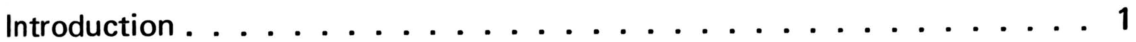

Literature Review . . . . . . . . . . . . . . . . . . 1

Materials and Methods . . . . . . . . . . . . 5

Results . . . . . . . . . . . . . . . 9

Drying Temperature $100^{\circ} \mathrm{C} \ldots \ldots \ldots \ldots 14$

Drying Temperature $85^{\circ} \mathrm{C} \ldots \ldots \ldots \ldots \ldots$

Drying Temperature $70^{\circ} \mathrm{C} \ldots \ldots \ldots \ldots \ldots$

Drying Temperature $55^{\circ} \mathrm{C} \ldots \ldots \ldots \ldots \ldots$

Drying Temperature $45^{\circ} \mathrm{C} \ldots \ldots \ldots \ldots \ldots$

Fatty Acids . . . . . . . . . . . . . . . 21

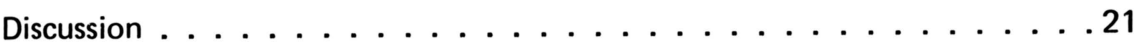

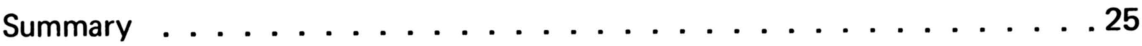

Literature Cited . . . . . . . . . . . . . . . . 26 
[Blank Page in Original Bulletin] 


\section{Some Microbial, Drying, and Odor Reduction Studies of Poultry Wastes}

\section{Susan Hurst Calderone and Harold A. Wilson}

\section{Introduction}

Disposal and/or use of poultry waste poses an increasing problem to the poultry operation as suburbia moves into previously rural areas. The value of the waste as an inexpensive soil-fertilizing additive has long been recognized but it is rarely used due to its offensive odor and because large amounts are required for adequate fertilization.

Poultry wastes, as a result of microbial activity, contain several groups of compounds which contribute to its obnoxious odor. These odors are not limited to the "chicken house" but invade surrounding areas. Disposal of the wastes as fertilizer could solve the disposal problem were it not for the odor.

This study involved the characterization of the nature and properties of poultry wastes and possible odor curtailment using microbial enzymes. The purpose was to determine drying times at various temperatures of poultry wastes collected under cage conditions, and, also, to investigate the possibility of odor reduction by enzymes, a commercial detergent-enzyme laundry aid, and certain bacteria.

\section{LITERATURE REVIEW}

The value of poultry waste, the most important by-product on the poultry farm, as a soil additive to increase productivity is generally accepted $(37,38)$. However, it is necessary to consider certain factors when studying its possible use: loss of fertilizing qualities and the disagreeable odors produced during storage, the attraction of flies and rodents, its potential as a disease carrier, and volume produced and amount needed to use as a fertilizer in its raw form.

Kidney excretions and feces are voided by poultry as a single product. In the waste the water content will vary depending upon age, environment, and other factors, but the amount of solids per day is rather constant. Hart (13) found an average defecation rate of $0.066 \mathrm{lb}$. total solids per hen-day. Poultry waste was found to have an average moisture content of 75 per cent and an average total solids content of 25 per cent. The total solids is broken down 
further to volatile and fixed solids (ash). Volatile solids or organic matter (average 76 per cent) is the material from which the odor originates due to microbial breakdown. Fixed solids averaged 24 per cent and is biologically inert material (31).

Biochemical oxygen demand (BOD) is an important characteristic of poultry waste, especially when examining methods of disposal. Hart (13) has found that the potential BOD for poultry waste should be considered to avoid the overloading of the disposal system. He calculated a BOD of $0.015 \mathrm{lb}$. per hen-day.

Poultry waste contains high percentages of nitrogen, phosphorus, and potassium which account for its value as a fertilizer. There are often wide variations in the amounts of major elements present in the wastes $(13,19,25)$. Some work also has been done to determine the amounts of major elements lost upon drying of the manure samples. Yushok and Bear (38) found that although some of the major elements were lost during drying, sufficiently high amounts remained to serve as fertilizing material. It should be noted that those qualities which make the waste a good fertilizer also make it attractive to fly breeding.

Poultry waste in its natural state is difficult to handle and causes considerable difficulties with respect to its offensive odor. The removal of water from the wastes has three advantages: (1) change in handling characteristics, (2) reduction in weight and volume, and (3) reduction in offensive odor (32).

Foul odors which are a result of anaerobic bacterial activity do not occur in dried fresh waste samples. This microbial activity is insignificant with low moisture content. The foul odor which results when microorganisms metabolize the waste and convert its higher order organic compounds into fatty acids (13) is present only when the waste has undergone microbial activity and is then dried $(14,32)$.

Poultry waste which is quickly dehydrated retains much of its fertilizing qualities. However, if raw waste is left without proper care, it will lose much of its nutrient value (19). Martin et al. (20) found that in waste stored without care the nitrogen content was reduced by 50 per cent or more, phosphorus by 4 per cent and potash by 11 per cent through fermentation and leaching.

There are three reported methods for removing water from animal wastes: mechanical, absorption, and thermal (32). Thermal removal is under consideration here.

Temperature, humidity, surface area and depth of the waste sample are some of the factors which must be considered in drying the sample. Sobel (32) found that drying of thin layers of material (1/4 to $1 / 8$ inch in depth) was most efficient.

Artificial drying results in loss of nitrogen and also of energy. It has been found that variable amounts of metabolizable energy and nitrogen are lost depending upon the temperature used (29). Yushok and Bear (38) earlier had 
found that even wastes treated to prevent nitrogen loss still showed high loss of nitrogen with artificial drying.

Poultry waste is reported to be a good breeding material for three common species of domestic flies (1) and supports untold numbers of microorganisms (13). This is a result of its moisture content and the nutrients and organic matter which are present.

In a study at the University of California at Davis (13) waste samples with a high percentage of solids content (water removed) showed a drastic reduction in the number of fly larvae present. It also would follow that with a reduction in moisture content there would be a reduction in the rumber of microorganisms metabolizing the fecal matter which contributes to the production of organic volatile acids and thereby the foul odor associated with poultry waste.

Diebel (10) reported that bacterial growth was related to the odor production but cited that pure cultures isolated from the poultry wastes failed to reproduce the odor under laboratory conditions. Coliforms were the main group of microorganisms found in fresh poultry waste; streptococci $\left(10^{5}\right.$ to $10^{8}$ bacteria per gram of manure) were the prevalent group in accumulated wastes.

Johansson et al. (17) reported that the microorganism most frequently isolated from the chicken intestinal tract was Escherichia coli. Fungi and yeasts were found to decrease in number with the increasing age of the waste (26). Coryneform bacteria have been found to be the major group present in poultry house deep litter $(26,28)$. Schefferle $(27)$ also reported aerobic bacteria to be responsible for the decomposition of uric acid to ammonia.

The formation of ammonia in poultry waste appears to be the result of the decomposition of uric acid by aerobic and anaerobic uricolytic bacteria. Sulfate-reducing bacteria, including Desulfovibrio spp., not only multiplied during the decomposition of liquid poultry wastes, but also were linked to the production of hydrogen sulfide (6).

The occurrence of animal and human pathogens is important when working with poultry waste. Cabes et al. (9) isolated ten suspected pathogens, all of which possessed Salmonella O antigen group D.

Alteration of its physical and chemical composition begins to occur as the waste is defecated into the environment. The changes are a result of the temperature, humidity, air, and surrounding environment.

Burnett (4) found that particulate matter served as an odor transport mechanism in chicken houses. This matter, upon drying at $100^{\circ} \mathrm{C}$, lost its characteristic chicken house odor, indicating that the odor was due to volatile compounds. Gas chromatographic analysis and organoleptic evaluations confirmed this.

Burnett and Dondero (6) reported an apparent relationship between odor intensity of liquid waste with length of storage time and increase in the concentration of volatile organic acids, ammonia and sulfides. Deibel (10) and 
Burnett (3) have reported that in addition to the above mentioned components, the odor of accumulated liquid poultry wastes also contains a mixture of hydrogen sulfide, diketones, mercaptans, indole, skatole, and other compounds.

There is little information reported on the decomposition of poultry waste, the intermediates contributing to the odors, or the microorganisms which are involved in the conversion to foul-smelling products.

The methods used for odor control include elimination by chemical, physical or mechanical means and modification due to masking by chemical means.

Yushok and Bear (38) deodorized poultry waste and reduced the loss of nitrogen with the addition of hydrated lime. The addition of lime also had a bactericidal effect on certain fowl pathogens and parasites.

Burnett and Dondero (7) demonstrated removal of 90 per cent or more of odor from poultry waste with a soil bed filtration method. However, where there is insufficient land available, some other treatment system is necessary.

The most common method of odor control is masking an undesirable odor with one that is more acceptable. This does not alter the odor but rather covers it up with a stronger odor. However, with animal wastes, the odor is so strong that the amount of masking odor needed to cover it up results in much added expense (35).

Odor counteraction is possible when two separate odors cancel each other. Waste odors, however, are a mixture of many odorous substances. Therefore, it becomes impossible to develop a gas that would cancel different odors since odors that counteract each other are specific (35). Faith (11), working with counteractants, masking agents, and disinfectants found a 1 per cent aqueous solution of potassium permanganate to be effective with waste from a cattle feedlot.

Benham (2) found the addition of sodium hydroxide to be effective in preventing development of malodors, but the cost was prohibitive.

Hammond et al. (12) used hydrated lime and Deibel (10) used chlorine as masking agents but found that quantities needed were too costly.

Burnett and Dondero (5) found that a most effective masking agent was an oil layer containing a powerful masking agent, Mosquito Larvae Oil, spread on the surface of liquid manure collection pits. However, the cost proved to be impractical (8).

Elimination of odorous gas has been studied using water and activated carbon, but because of the quantities necessary, the studies were abandoned (35).

Additions of bacterial starter cultures and digestive enzymes (digestive deodorants) proved to be ineffective $(5,10)$. Johnson et al. $(18)$ used several commercial preparations containing enzymes and bacteria. The manufacturers claimed the preparations enhanced bacterial action in converting protein and other nitrogenous material into ammonia. The bacteria then use some of the 
ammonia for growth and convert the rest to nitrates. The conclusion is that since nitrates are odorless, the odor of the poultry waste is reduced because the nitrogen is not escaping as ammonia. The investigators found that although the preparations sometimes bring about a reduction in volume, there is little or no effect on the moisture content (as claimed by the manufacturers) or on the odor.

\section{MATERIALS AND METHODS}

The poultry waste used in this study was obtained from laying hens at the West Virginia University Poultry Farm in Morgantown. Random collections were made and combined to obtain a representative sample (bulk sample). In the laboratory all feathers, feed, and maggots that could possibly be removed were removed by sorting. The feces were then thoroughly mixed.

One hundred-gram subsamples were taken from the bulk samples, divided into duplicate $50 \mathrm{-g}$ samples, and mositure, dry matter, volatile solids and ash determinations were made (33). The duplicate $50 \mathrm{~g}$ samples were weighed into tared evaporating dishes and dried at $103 \pm 1^{\circ} \mathrm{C}$ for 16 hours. After drying and weighing the moisture and dry matter of the samples were calculated. The dried samples were then placed in a muffle furnace at $600^{\circ} \mathrm{C}$ for 1.5 hours, cooled, weighed, and the volatile solids and ash calculated. Since poultry waste averages close to 75 per cent moisture, any bulk sample which deviated more than 2 per cent from the published averages was discarded as not representative. After removing the $100-\mathrm{g}$ sample, the bulk sample was stored in a closed container at $5^{\circ} \mathrm{C}$. This temperature slowed microbial activity, maintained the moisture level, and avoided the detrimental effects of freezing.

Total nitrogen and phosphorus were determined on some of the bulk samples. These analyses were made on moist waste, and the results calculated on an oven dry basis. Each bulk sample also was subjected to one or more of the following analyses, but no one sample was analyzed for all: biochemical oxygen demand (BOD) drying weight at different time intervals at various temperatures, bacterial density at various stages of drying, resistance to heat of certain bacterial isolates, bacterial density change in stored poultry waste, odor curtailment, and the presence of $\mathrm{C}_{2}-\mathrm{C}_{6}$ fatty acids.

Biochemical Oxygen Demand: This determination was made using the Hach* BOD manometric apparatus and procedure. The subsample and distilled water were placed at $20^{\circ} \mathrm{C}$ for approximately 2 hours for temperature equilibration. Then $10 \mathrm{~g}$ of the sample were added to $300 \mathrm{ml}$ of the water, and blended in a Waring blender for about five seconds at 1-minute intervals for 3 minutes. This interval mixing was to avoid a temperature rise. The slurry was then diluted to 11 with distilled water at $20^{\circ} \mathrm{C}$ and placed on a magnetic stirrer

*Hach Chemical Co., Ames, Iowa. 
to keep all solids in suspension, and 157-ml portions were quickly removed and added to the Hach BOD bottles. The bottles and contents were then placed upon the BOD apparatus and allowed to equilibrate for $\mathbf{3 0}$ minutes before closing the system. Daily readings of oxygen uptake were taken for five days. Incubation was at $20^{\circ} \mathrm{C}$.

Dry Rate and Rate of Water Loss: The drying rate of poultry waste was determined at $100^{\circ}, 85^{\circ}, 70^{\circ}$, and $45^{\circ} \mathrm{C}$. No drying termperature less than $45^{\circ} \mathrm{C}$ was used since the average chicken temperature is $40-41^{\circ} \mathrm{C}$.

A series of $25-\mathrm{g}$ portions were weighed from a thoroughly mixed bulk sample into metal weighing pans and placed at the various temperatures in drying ovens. At intervals a sample was removed, cooled and weighed. This procedure was followed until constant weight was obtained. The weighing intervals were as follows: $100^{\circ} \mathrm{C}-30 \mathrm{~min}, 85^{\circ} \mathrm{C}-1 \mathrm{hr}, 70^{\circ} \mathrm{C}-1 \mathrm{hr}, 55^{\circ} \mathrm{C}-2$ $\mathrm{hr}$, and $45^{\circ} \mathrm{C}-2 \mathrm{hr}$. From the data the rate of drying was plotted as well as the rate of water loss.

Effect of Drying Upon Bacterial Numbers: The rate of bacterial kill was determined upon poultry waste at $0,1 / 4,1 / 2,3 / 4$, and complete drying at $100^{\circ}$, $85^{\circ}, 70^{\circ}, 55^{\circ}$, and $45^{\circ} \mathrm{C}$. The time intervals at which samples were removed from the drying ovens and determinations made are shown in Table 1.

\section{TABLE 1.}

Time intervals at which samples were removed from the drying ovens for each temperature.

\begin{tabular}{cccccr}
\hline \hline & \multicolumn{5}{c}{ Stage of Drying (in hrs.) } \\
$\begin{array}{c}\text { Temperature } \\
\text { C }\end{array}$ & 0 & $1 / 4$ & $1 / 2$ & $3 / 4$ & Dry \\
\hline 100 & 0 & 2.00 & 4.00 & 6.00 & 8.00 \\
85 & 0 & 2.25 & 4.50 & 6.75 & 9.00 \\
70 & 0 & 2.75 & 5.50 & 8.25 & 11.00 \\
55 & 0 & 5.50 & 11.00 & 16.50 & 22.00 \\
45 & 0 & 7.50 & 15.00 & 22.50 & 30.00
\end{tabular}

Upon removal from the drying oven a sample was allowed to cool in a desiccator and weighed. The partially or completely dry waste was quickly ground in a sterile mortar and pestle and a quantity equivalent to $1 \mathrm{~g}$ (oven dry basis) weighed and added to a sterile water blank to yield a $10^{-1}$ dilution. Further dilutions were made and plated using Standard Plate Count Agar, ${ }^{* *}$

**Difco Co., Detroit, Michigan. 
according to Standard Methods (33). The dilutions were plated in quintuplet and each bacterial analysis at each temperature and time was repeated on three different bulk samples. Plate incubation was at $25^{\circ} \mathrm{C}$ for five days.

Sporeforming bacteria were determined by heating each dilution at $80^{\circ} \mathrm{C}$ for 10 minutes to kill the vegetative cells. The dilutions were then plated and incubated as above.

The plates to be incubated under anaerobic conditions were placed in large chromatographic jars. A square of stainless steel was sealed with plasticine as a cover for each jar. Anaerobic conditions were obtained by Parker's method (22). Small beakers containing equal volumes of $\mathrm{NaHCO}_{3}$ and $\mathrm{CaCO}_{3}$ solutions were placed in the chromatographic jars to increase the $\mathrm{CO}_{2}$ level. Small vials of methylene blue were used as O-R indicators. A slight modification to Parker's method was the placing of a lighted candle in a jar just before sealing the cover to reduce more quickly the $\mathrm{O}_{2}$ content within the jar. Incubation time and temperature were as given above.

Isolation of Bacteria and Fungi: Some bacteria were found to survive in poultry waste dried at $100^{\circ} \mathrm{C}$ for 8 hours. These organisms were isolated and identified. The isolates were maintained on Standard Methods Agar. ${ }^{* *}$

Fungal density was determined on unheated samples. Cooke's Rose Bengal Agar ${ }^{* *}$ with $30 \mu \mathrm{g} / 1$ streptomycin was the plating medium.

Heat Resistance of the 23 Isolates: Since these bacteria had been isolated from waste dried at $100^{\circ} \mathrm{C}$ for 8 hours their resistance to this temperature as pure cultures was determined.

Ten $\mathrm{ml}$ of a pure culture grown in Trypticase Soy Broth ${ }^{* *}$ was added to $25 \mathrm{~g}$ sterile sand and placed in a drying oven at $101 \pm 1 \mathrm{C}$. At hourly intervals for 15 hours a small amount of sand was aseptically transferred to a tube of the above medium, incubated at $37^{\circ} \mathrm{C}$ for 24 hours, and then examined for growth.

Effect of Storage on Numbers of Certain Bacterial Groups: The poultry waste used in this study had been defecated less than 12 hours before the zero time as indicated on the figures presenting the results.

The following bacterial enumerations were made: total aerobic, total anaerobic, coliforms, fecal streptococci, aerobic uric acid decomposers, anaerobic uric acid decomposers, and sulfate reducers.

The above determinations were made every 48 hours. The media employed included: Trypticase Soy Agar, $^{\dagger}{ }^{\dagger}$ Brewers Anaerobic Agar, ${ }^{\dagger}$ Levine's Methylene Blue Agar, ${ }^{* *}$ and Azide Agar. ${ }^{*}$ The method of Schefferle as modified by Burnett and Dondero (6) was used to follow the uric acid decomposers, and the sulfate reducers were determined using the method of Postgate (24). The anaerobic uric acid decomposers were cultured in Brewer anaerobic jars. The pipette method of Thompson (36) was used to determine the number of

* *Difco Co., Detroit, Michigan.

tBBL, Cockeysville, Maryland 21030. 
anaerobes. All inoculations were incubated at $25^{\circ} \mathrm{C}$ for five days, except the anaerobic uric acid decomposers which were incubated for seven days.

The bulk samples used in the study were maintained at constant moisture at $5^{\circ} \mathrm{C}$.

Odor Reduction: Odor reduction studies were conducted in two parts. The first was qualitative; the data being obtained by a five-member panel "sniffing" the manure samples after treatment. The second was quantitative based upon the reduction of acetic, propionic, butyric, isobutyric, and isovaleric acids.

1. Panel-Qualitative. The poultry waste was dried at $45^{\circ} \mathrm{C}$, ground in a Wiley mill and 20-g samples weighed into separate beakers. Bacillus subtilis and Proteus vulgaris were among those chosen to be used alone and in combination for treatments because they produced certain extracellular enzymes, according to the literature. The organisms were obtained from the stock culture collection of the Division of Plant Sciences, West Virginia University. Before use, all cultures were tested for growth and enzyme production on the following media: (1) Gelatin Agar (30); Casein Agar (23); Tributyrin Agar (23); Chicken Manure Extract Agar (6). The laundry detergent-enzyme Biz ${ }^{\dagger \dagger}$ also was included in the study.

Twenty-gram samples of the oven dry $\left(45^{\circ} \mathrm{C}\right)$ ground waste were treated with $15 \mathrm{ml}$ broth suspension of each of the above bacteria. The suspensions were adjusted to give a 11 per cent transmission at $660 \mathrm{~m} \mu$ reading. The organisms were used individually and in combinations and with a saturated solution of Biz. The controls were treated with $15 \mathrm{ml}$ distilled water. Duplicate samples were incubated at $37^{\circ} \mathrm{C}$ and $45^{\circ} \mathrm{C}$ for 24 hours at constant moisture. The samples were then oven dried $\left(45^{\circ} \mathrm{C}\right)$ and moistened with odor-free water (33). The panel members picked those with the least offensive odor. Those organisms eliminated by the qualitative test included Bacillus cereus, Serratia marcescens, Staphylococcus aureus and Pseudomonas fluorescens.

2. Analytical-Quantitative. Based upon the findings of the panel, Bacillus subtilis, Proteus vulgaris, and Biz were chosen for further study.

Twenty-gram dried and ground waste samples were treated as follows (except "a," which was moist, unheated waste):

Unheated

a. No treatment (unheated control)

Heated to Dryness $\left(45^{\circ} \mathrm{C}\right)$

b. No treatment

c. $P$. vulgaris enzyme extract added

d. B. subtilis enzyme extract added

e. Lipase added

f. Biz added

g. Biz enzyme added

t†Proctor and Gamble, Cincinnati. 
The treatment materials were as follows: A. $P$. vulgaris and $B$. Subtilis enzyme extracts. Each organism was grown in $250 \mathrm{ml}$ nutrient broth for 36 hours at $37^{\circ}$ $C$ and then centrifuged. The supernatant was saved. The extracellular enzymes were precipitated with saturated $\left(\mathrm{NH}_{4}\right)_{2} \mathrm{SO}_{4}$. The enzymes were resuspended in $20 \mathrm{ml}$ distilled water. B. One gram commercially prepared lipase (hog pancreas) added to $2 \mathrm{~g}$ sodium taurocholate (lipase enhancer). C. Biz enzyme, one gram enzyme preparation such as found in commercially prepared detergents (Monsanto: SG-2485N; equivalent to 2.5 units of neutral protease; $A=657 \mathrm{M}$ units alkaline protease; $\mathrm{a}+650$ units amylase).

Fatty Acid Extraction: The methods of Hindin et al. (15) were used to determine the volatile $\mathrm{C}_{2}-\mathrm{C}_{6}$ group of organic acids. Distilled water was added to the manure samples to bring the volumes to $100 \mathrm{ml}$. The samples were incubated at $37^{\circ} \mathrm{C}$ for 24 hours. After incubation, $\mathrm{H}_{3} \mathrm{PO}_{4}$ was added to lower the $\mathrm{pH}$ to approximately 2.0 and then the samples were centrifuged at $10,000 \times \mathrm{g}$ for 30 minutes. The supernatant was stored at $0^{\circ} \mathrm{C}$.

A $2 \mu$ portion of the supernatant was injected into the gas-liquid chromatograph. The chromatograph conditions were as follows:

Column temp. ....................... $145^{\circ} \mathrm{C}$.

Program rate $\ldots \ldots \ldots \ldots \ldots \ldots \ldots \ldots \ldots$ isothermal

Detection temp.................... $207^{\circ} \mathrm{C}$

Injection temp. ......................205

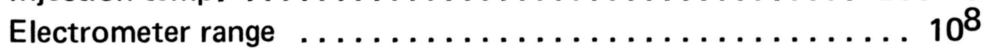

Carrier flow .....................40 cc/min

Air (to detector) ................. $400 \mathrm{cc} / \mathrm{min}$

Hydrogen (to detector) ............... $40 \mathrm{cc} / \mathrm{min}$

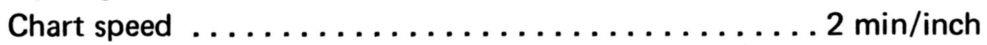

\section{RESULTS}

Bulk Sample Analysis: The percentage of moisture, ash volatile solids, and dry matter averages and range of all samples used are shown in Table 2. The total nitrogen and phosphorus average per cent on random samples in both moist and dry conditions, as well as per cent loss on drying, are shown in Table 3.

Drying of poultry waste even at a temperature of $45^{\circ} \mathrm{C}$, slightly above the average temperature of chickens $\left(40-41^{\circ} \mathrm{C}\right)$, results in a loss of about 21 per cent nitrogen and about 6 per cent phosphorus.

Biochemical Oxygen Demand (BOD): The five-day BOD curve is shown in Figure 1. The five-day demand of $340 \mathrm{mg} / \mathrm{l}$ of oxygen is somewhat greater than the average of domestic raw sewage which is about $240 \mathrm{mg} / \mathrm{l}$. The comparable $\mathrm{pH}$ levels of the poultry manure slurry and domestic raw sewage are 8.2 and 7.3 (range 6.0 to 8.5 ) respectively. 
TABLE 2.

Poultry waste characteristics.

\begin{tabular}{lcc}
\hline & $\begin{array}{c}\text { Average } \\
\text { (per cent) }\end{array}$ & $\begin{array}{c}\text { Range } \\
\text { (per cent) }\end{array}$ \\
\hline Solids & 24.76 & $21.05-30.30$ \\
Moisture & 75.23 & $67.70-78.95$ \\
Ash & 30.29 & $23.85-41.10$ \\
Volatile material & 69.71 & $58.90-76.15$ \\
\hline
\end{tabular}

\section{TABLE 3.}

Nitrogen and phosphorus content of poultry waste samples-fresh waste and oven-dried at $45^{\circ} \mathrm{C}$.

\begin{tabular}{lccr}
\hline \hline & $\begin{array}{c}\text { Moist } \\
\text { (based on oven-dried) } \\
\text { (per cent) }\end{array}$ & $\begin{array}{c}\text { Dried } \\
\text { (per cent) }\end{array}$ & $\begin{array}{c}\text { Loss } \\
\text { (per cent) }\end{array}$ \\
\hline Nitrogen & 3.66 & 2.90 & 20.76 \\
Phosphorus & 2.86 & 2.69 & 5.94 \\
\hline
\end{tabular}

Drying Rate: Reduction in bulk and weight are two of the desired goals in poultry waste handling. These can be partially obtained by drying. An important aspect of drying is the relationship between temperature and time.

Drying times were determined on 15 bulk samples during the course of this study. The drying time variations among the bulk samples were negligible, therefore Figure 2, which represents typical drying rate data, is based upon the results obtained from one bulk sample.

At the $45^{\circ} \mathrm{C}$ drying temperature 30 hours were required for the $25 \mathrm{~g}$ samples to reach constant weight but only 8 hours at $100^{\circ} \mathrm{C}$. The difference in drying time at $70^{\circ} \mathrm{C}$ and $100^{\circ} \mathrm{C}$ was only 3 hours and between $55^{\circ} \mathrm{C}$ and $45^{\circ}$ $C$ it was 8 hours. The temperature differences were 30 and 10 degrees respectively. 


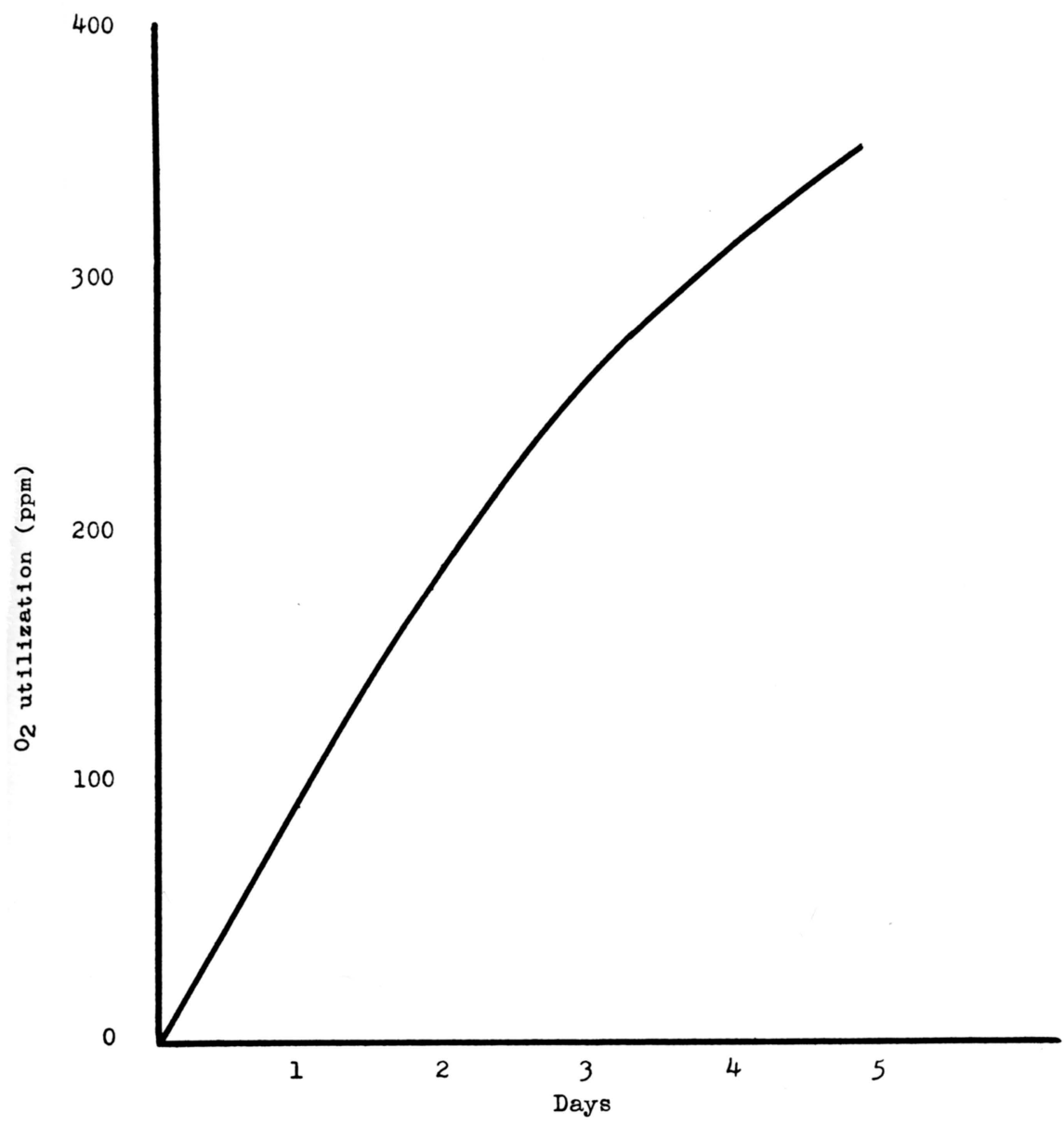

Figure 1. $\mathrm{O}_{2}$ utilization during a five-day BOD determination on a waste-water slurry sample.

Rate of Water Loss: The percentages of moisture remaining in waste samples at $0,1 / 4,1 / 2$, and $3 / 4$ 's of the time necessary to obtain complete dryness (constant weight) at various temperatures are presented in Table 4.

The greatest water loss at $100^{\circ} \mathrm{C}$ and $85^{\circ} \mathrm{C}$ occurred during the first quarter of the drying time but during the last quarter for $70^{\circ} \mathrm{C}, 55^{\circ} \mathrm{C}$, and $45^{\circ}$ C. At $55^{\circ} \mathrm{C}$ and $45^{\circ} \mathrm{C}$ the water loss was essentially the same for the first two quarter intervals and increased during the last two. 


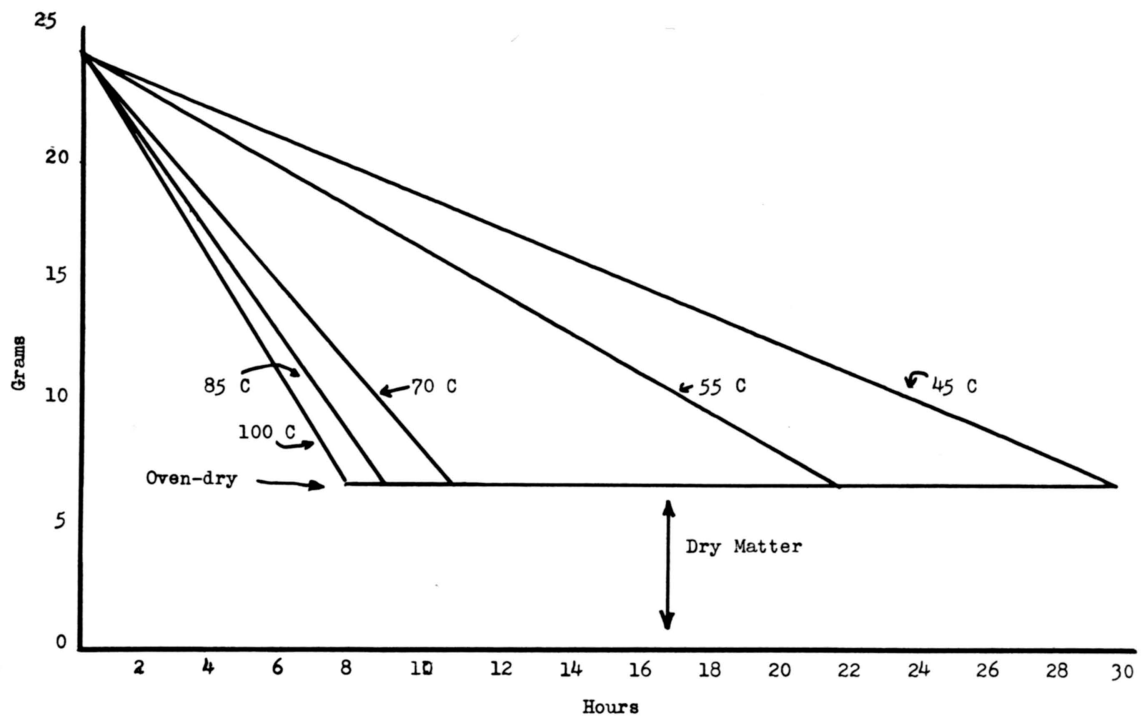

Figure 2. Rate of drying for 25-g samples of poultry waste at $100^{\circ} \mathrm{C}, 85^{\circ} \mathrm{C}$, $70^{\circ} \mathrm{C}, 55^{\circ} \mathrm{C}$, and $45^{\circ} \mathrm{C}$.

Effect of Drying Upon Bacterial Numbers: Desiccation and heat have a lethal effect upon certain bacteria in mixed populations. Consequently, drying of poultry waste will reduce its microbial population, possibly resulting in some change in those odor characteristics which are caused by microbial activity.

The numbers of total aerobes, total anaerobes, aerobic sporeformers, and anaerobic sporeformers present at various stages during the drying regime are

TABLE 4.

Amount of water (per cent) present at each time period in poultry waste sample during drying.

\begin{tabular}{cccccc}
\hline \hline Temperature & 0 hrs & $1 / 4$ & $1 / 2$ & $3 / 4$ & full \\
\hline $100 \mathrm{C}$ & 75 & 40 & 24 & 10 & 0 \\
85 & 75 & 48 & 30 & 16 & 0 \\
70 & 75 & 55 & 41 & 23 & 0 \\
55 & 75 & 63 & 53 & 32 & 0 \\
45 & 75 & 64 & 54 & 36 & 0 \\
\hline
\end{tabular}


shown in Figures 3 through 7. Each curve is from one representative sample, rather than an average of all determinations because of sample variation, age, condition of the poultry, and the initial microbial count.

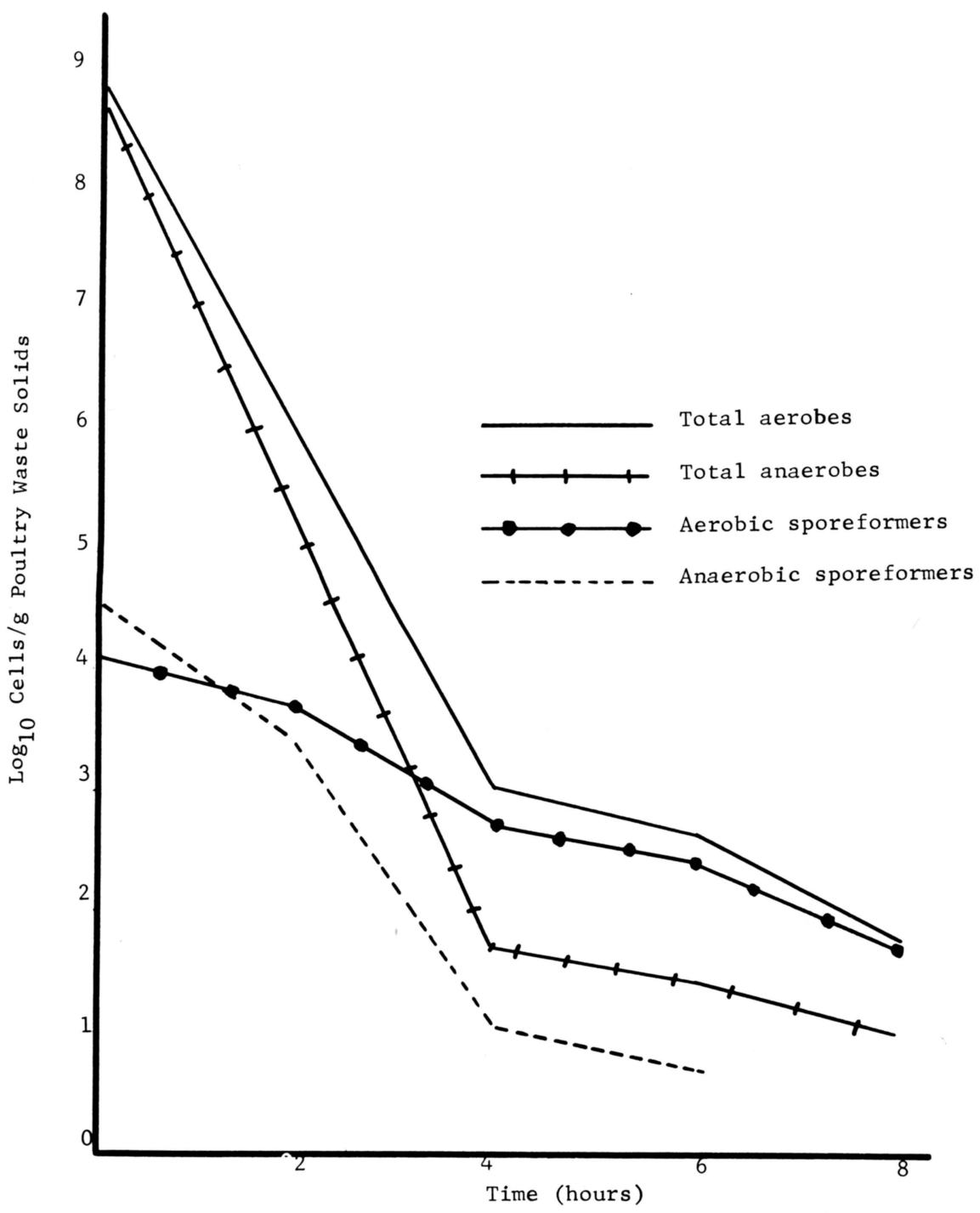

Figure 3. Effect of heat $\left(100^{\circ} \mathrm{C}\right.$ dry heat) on bacterial numbers from poultry waste sample (plates incubated at $25^{\circ} \mathrm{C}$ for five days). 


\section{Drying Temperature $100^{\circ} \mathrm{C}$}

Within the first 2 hours of the drying time the total bacterial population was reduced 99 per cent. Utilizing another sample and determining the microbial densities at 30-minute intervals during the first 2 hours of drying showed that the most rapid rate of reduction occurred within the first 30 minutes. In this sample the bacterial numbers were reduced from $3.5 \times 10^{7}$ to $2.0 \times 10^{5}$ cells (O.D. basis). Some bacteria survived in all samples dried at $100 \mathrm{C}$ (Figure 3).

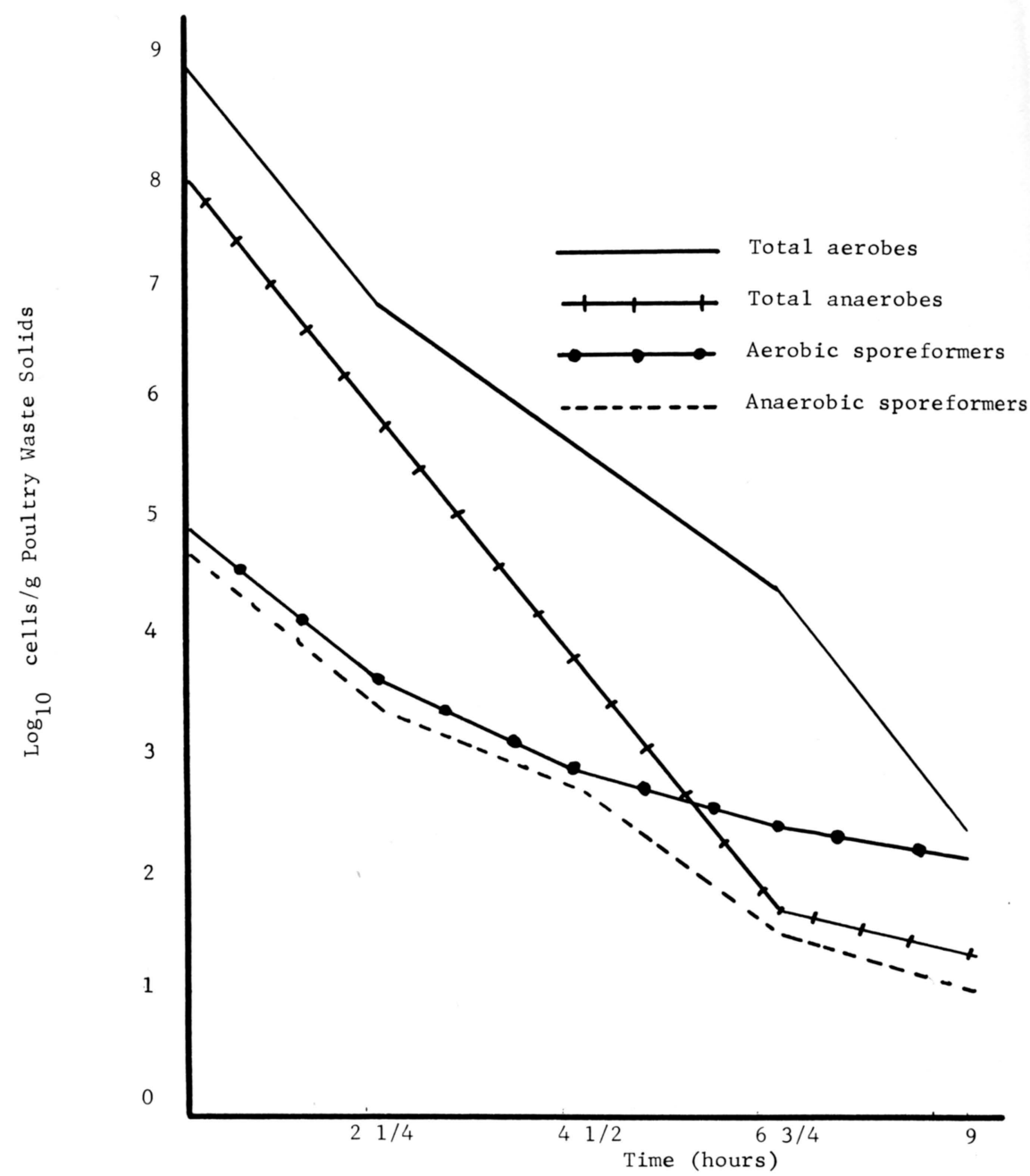

Figure 4. Effect of heat ( $85^{\circ} \mathrm{C}$ dry heat) on bacterial numbers from poultry waste sample (plates incubated at $25^{\circ} \mathrm{C}$ for five days). 


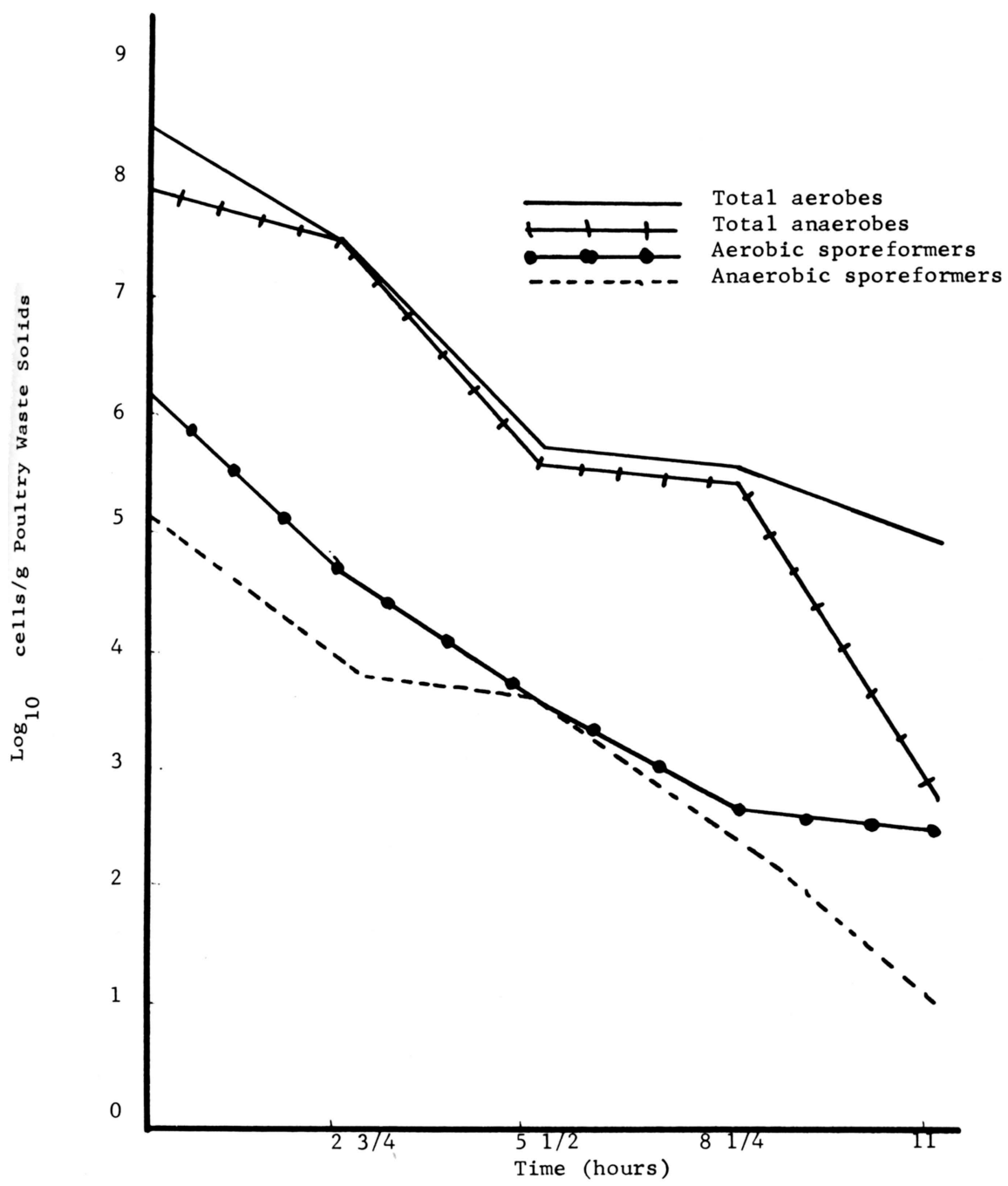

Figure 5. Effect of heat $\left(70^{\circ} \mathrm{C}\right.$ dry heat) on bacterial numbers from poultry waste sample (plates incubated at $25^{\circ} \mathrm{C}$ for five days). 


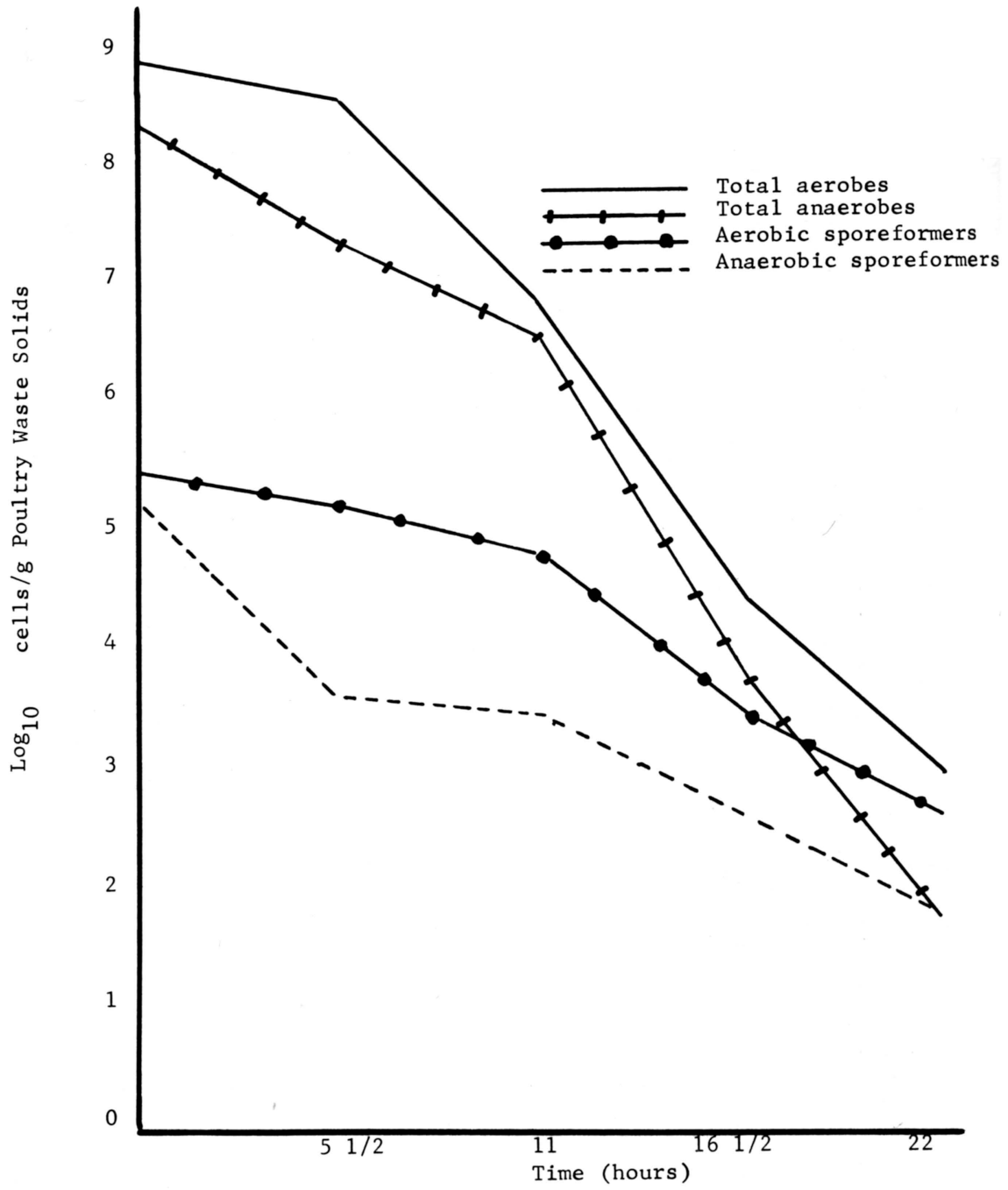

Figure 6. Effect of heat ( $55^{\circ} \mathrm{C}$ dry heat) on bacterial numbers from poultry waste sample (plates incubated at $25^{\circ} \mathrm{C}$ for five days). 


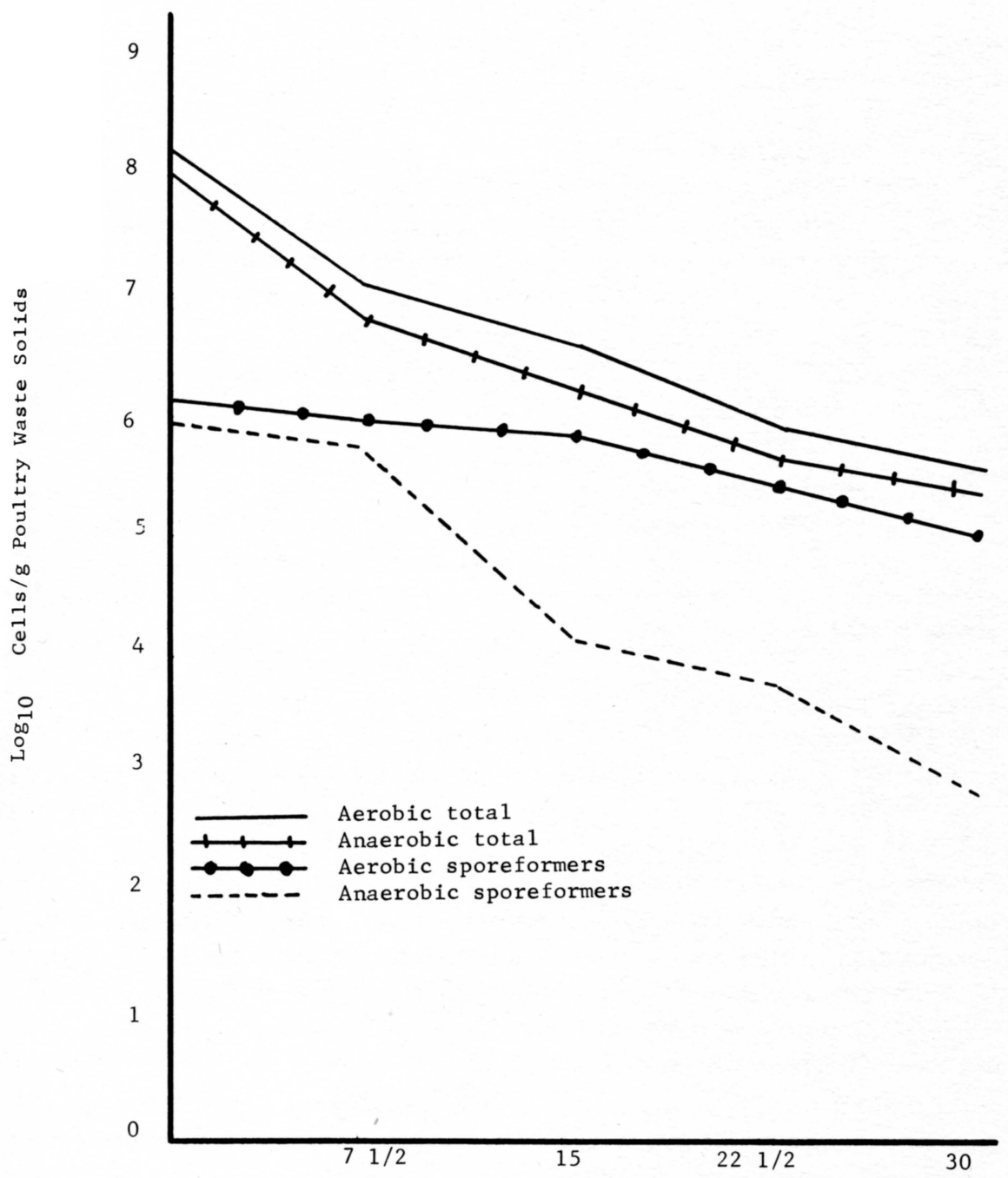

Figure 7. Effect of heat $\left(45^{\circ} \mathrm{C}\right)$ on bacterial numbers from poultry waste sample (plates incubated at $25^{\circ} \mathrm{C}$ for five days). 


\section{Drying Temperature $85^{\circ} \mathrm{C}$}

Although all anaerobic sporeforming bacteria died during drying at $100^{\circ} \mathrm{C}$ there were survivors after drying at $85^{\circ} \mathrm{C}$. Numbers of aerobes and aerobic sporeformers were higher after drying at $85^{\circ} \mathrm{C}$ than at $100^{\circ} \mathrm{C}$ (Figure 4).

\section{Drying Temperature $70^{\circ} \mathrm{C}$}

Total aerobes, total anaerobes, and aerobic sporeformers survived much better at $70^{\circ} \mathrm{C}$ drying than at $100^{\circ} \mathrm{C}$ and $85^{\circ} \mathrm{C}$ (Figure 5). However, the anaerobic sporeformers seem to be as susceptible at this temperature as to the two higher temperatures used. The density of total aerobes in the waste dried at $70^{\circ} \mathrm{C}$ is much greater than that at dryness attained at $55^{\circ} \mathrm{C}$ and about the same as at $45^{\circ} \mathrm{C}$. This is a deviation from the general trend which is evident as shown in Figures 5 through 7.

\section{Drying Temperature $55^{\circ} \mathrm{C}$}

The anaerobic sporeformers showed somewhat more resistance to drying at $55^{\circ} \mathrm{C}$ than at the higher drying temperatures used (Figure 6). The aerobes and anaerobes died at essentially the same rate throughout the entire drying period of 22 hours.

\section{Drying Temperature $45^{\circ} \mathrm{C}$}

The aerobes and anaerobes were killed at $45^{\circ} \mathrm{C}$ drying temperature at essentially the same rate. In general, this parallelism occurred at all temperatures used. Although all groups were reduced during the 30-hour drying period the reduction was less with all, except the anaerobic sporeformers (Figure 7).

Isolation of Bacteria and Fungi: The only isolation and identification of bacteria were those which survived in the manure samples dried at $100^{\circ} \mathrm{C}$. Twenty-three aerobes or facultative anaerobes were isolated. Seven of these were identified as Bacillus stearothermophilus and six as Bacillus coagulans.

Four microaerophilic isolates identified as Lactobacillus spp. were obtained. Eight other isolates were identified as species of Clostridium.

Fungal density in unheated poultry waste averaged $20.8 \times 10^{4} / \mathrm{g}$ of solids. The predominant genera were Aspergillus and Penicillium. Fungal colonies were often encountered on agar plates made for bacterial enumeration from poultry dried at $55^{\circ} \mathrm{C}$ and $45^{\circ} \mathrm{C}$. However, neither isolations nor identifications were made.

Heat Resistance of the 23 Bacterial Isolates: All of the bacterial isolates withstood a temperature of $101+1^{\circ} \mathrm{C}$ up to 15 hours in pure cultures.

Effect of Storage on Numbers of Certain Bacterial Groups: This study was undertaken using five different samples over a period of time. Analyses involving each sample were terminated after eight days because of the appearance of fly 
maggots after six to eight days. Storage was at room temperature.

The numbers of aerobic bacteria increased rapidly from the initial density (Figure 8). After the fourth day the rate of increase, however, was less rapid. The increase in anaerobic numbers followed the same general trend as the aerobic numbers and the actual overall rate increase was slightly greater but the density of the anaerobes never reached the density of the aerobes.

At zero time the number of coliforms (Figure 8 ) was greater than the

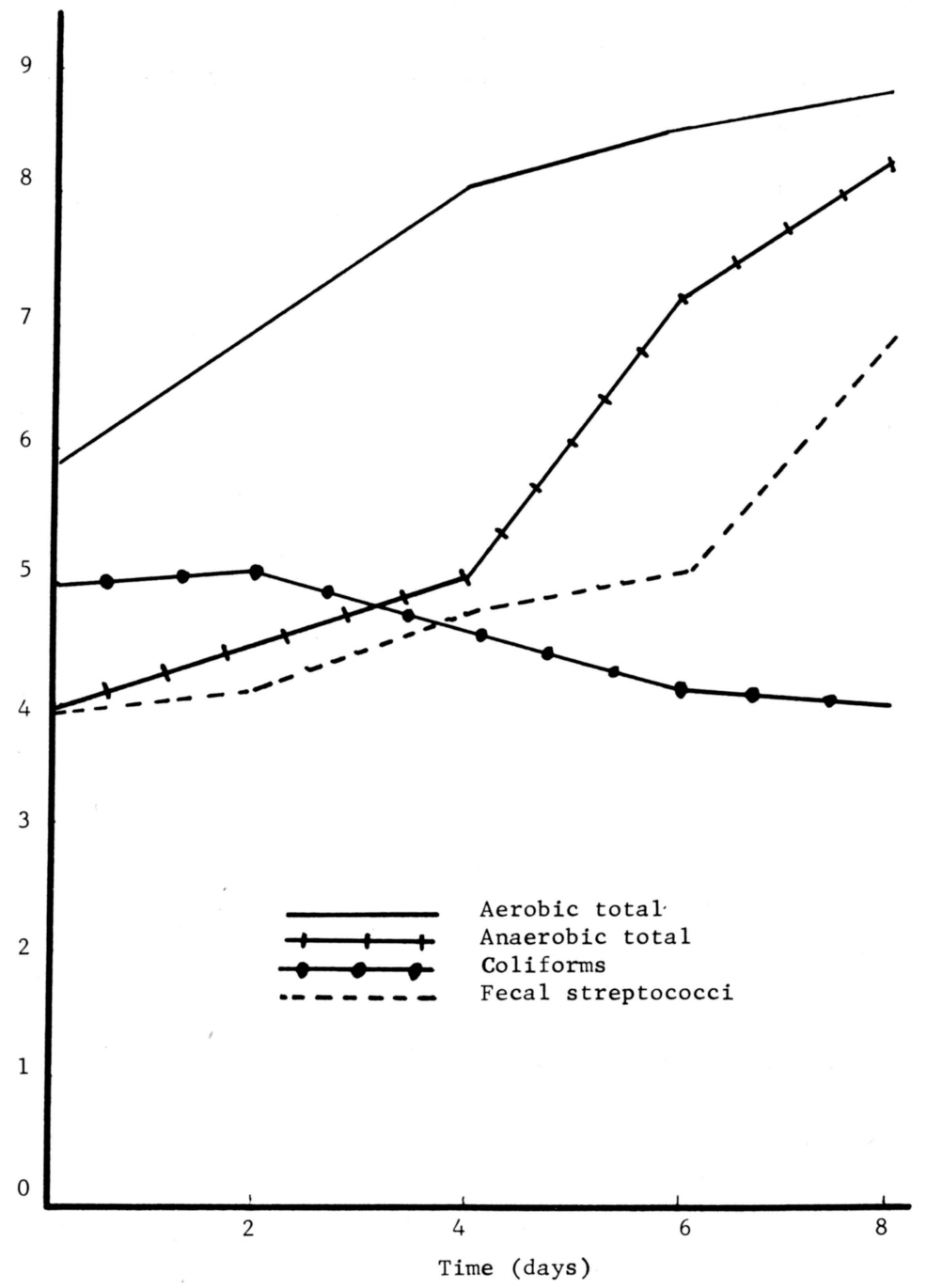

Figure 8. Succession of microorganisms in stored poultry wastes. 
number of fecal streptococci. After the second day the coliform count began to decline and that of the fecal streptococci began to increase.

The numbers of aerobic and anaerobic uric acid decomposers reached their maxima on the second day and then sharply declined to the fourth day (Figure $9)$. The anaerobic uric acid decomposers declined from $5 \times 10^{6}$ on the second day to about $1 \times 10^{6}$ by the fourth day and remained at that level to the eighth day when the study was terminated. The aerobic uric acid decomposers continued to decline after the fourth day at a somewhat slower rate than between the second and fourth day.

After the fourth day the sulfate reducers showed an increase in rate of growth (Figure 9).

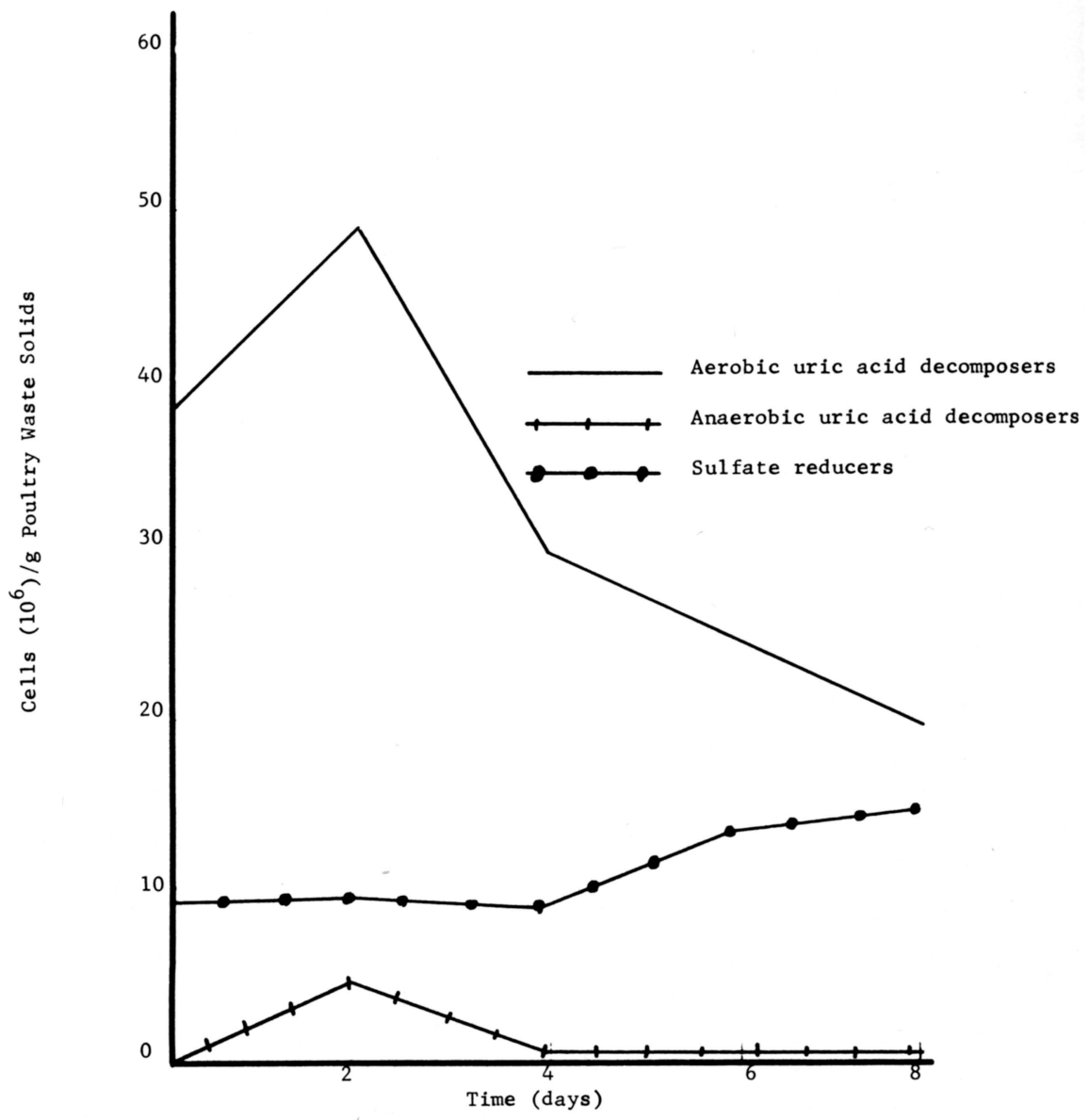

Figure 9. Effect of storage on numbers of aerobic and anaerobic uric acid decomposers and sulfate reducers. 
Odor Reduction: Manure samples treated with B. subtilis, $P$. vulgaris and Biz had the least objectionable odor of all the treatments, according to the panel members. The $P$. vulgaris-Biz treated sample had a slightly more offensive odor. The results are presented in Table 5 .

\section{Fatty Acids}

The quantitative data were based upon the reduction of acetic, propionic, butyric, isobutyric and isovaleric acids and are presented in Table 6.

Drying alone reduced the acetic, propionic, butyric, and isobutyric acids in the range of 43 to 54 per cent. The strong offensive odor present during the heating process was an indication of a change taking place.

The enzyme extract $P$. vulgaris slightly reduced the quantity of all five acids compared to the heat treated manure. B. subtilis enzyme extract had only a slight reducing effect upon acetic and butyric acids as compared to the quantity of those acids in the heat-treated manure sample. Commercial lipase was most effective reducing the quantity of butyric and isobutyric acids and Biz had no effect on any acid. However, the Biz enzyme (less the detergent) was effective in reducing the quantity of all the five acids below the levels present in the heat-treated sample.

\section{DISCUSSION}

The bulk analyses of the samples of poultry waste used in this study were found to be quite close to those reported earlier by Sobel (32). The average moisture content (75 per cent) and solids (25 per cent) were considered to be reliable indicators of the uniformity of the samples.

The amount of volatile material as opposed to ash content is an important consideration when poultry waste is being used as a fertilizer. Additionally, it is important to consider the nitrogen and phosphorus content of such manure. The high percentages of these two elements, along with their availability make poultry waste desirable as a fertilizer. The inconvenience of poultry waste bulk can be lessened by drying, however, about 21 per cent of the nitrogen and nearly 6 per cent of the phosphorus are lost. Nevertheless, the material is still a good fertilizer, as shown by Yushok and Bear (38).

The BOD is a test "for the determination of the organic strength of sewage." Essentially, it is the measurement of the oxygen utilized in the stabilization of the organic matter in sewage by microorganisms . . " (21). ${ }^{1}$ To use this analysis as a rough measure of the organic matter in poultry waste a slurry must be used. A 1:100 dilution of moist poultry waste had a five-day BOD value of $340 \mathrm{mg} / \mathrm{l}$ oxygen. This is somewhat stronger than domestic sewage

${ }^{1}$ Author's note: This refers to raw sewage. 
TABLE 5.

Quantitative results of odor reaction as determined by sensory panel.

\begin{tabular}{|c|c|c|c|c|c|c|c|}
\hline $\begin{array}{l}\text { Organism or } \\
\text { Additive }\end{array}$ & $\begin{array}{l}\text { Bacillus } \\
\text { subtilis }\end{array}$ & $\begin{array}{l}\text { Bacillus } \\
\text { cereus }\end{array}$ & $\begin{array}{l}\text { Staphlo- } \\
\text { coccus } \\
\text { aureus }\end{array}$ & $\begin{array}{c}\text { Serratia } \\
\text { marcescens }\end{array}$ & $\begin{array}{l}\text { Proteus } \\
\text { vulgaris }\end{array}$ & $\begin{array}{l}\text { Pseudomonas } \\
\text { fluorescens }\end{array}$ & Biz \\
\hline Bacillus subtilis & $5^{*}$ & 1 & - & - & $\cdot$ & $\cdot$ & 2 \\
\hline Bacillus cereus & 1 & 1 & - & - & - & - & - \\
\hline Staphlococcus aureus & - & - & - & - & $\cdot$ & $\cdot$ & - \\
\hline Serratia marcescens & - & - & - & - & $\cdot$ & $\cdot$ & - \\
\hline Pseudomonas fluorescens & - & - & - & $\cdot$ & $\cdot$ & - & - \\
\hline Proteus vulgaris & 1 & 2 & - & - & 5 & $\cdot$ & 3 \\
\hline $\mathrm{Biz}$ & 2 & - & - & - & - & - & 5 \\
\hline
\end{tabular}

* Number indicates those of the panel favoring that combination as least offensive.

-Indicates no panel members favoring that combination. 
TABLE 6.

Reduction of short chain fatty acids in poultry wastes.

\begin{tabular}{|c|c|c|c|c|c|}
\hline \multirow[b]{2}{*}{ Untreated } & \multirow{2}{*}{$\begin{array}{c}\text { Acetic } \\
40.0\end{array}$} & \multicolumn{2}{|c|}{$\begin{array}{c}\text { Propionic Isobutyric } \\
\text { (mg fatty acid/g solid waste) }\end{array}$} & Butyric & \multirow{2}{*}{$\begin{array}{c}\text { Isovaleric } \\
3.20\end{array}$} \\
\hline & & 12.70 & 2.10 & 10.30 & \\
\hline Heat treated & 25.0 & 5.90 & 1.40 & 5.50 & 3.50 \\
\hline $\begin{array}{l}\text { Proteus vulgaris } \mathrm{e} \\
\quad \text { extract }\end{array}$ & 21.4 & 4.0 & .70 & 3.70 & 2.55 \\
\hline $\begin{array}{l}\text { Bacillus subtilis e } \\
\quad \text { extract }\end{array}$ & 22.5 & 5.90 & 1.40 & 5.20 & 3.85 \\
\hline Lipase & 21.4 & 5.0 & 1.05 & 1.10 & 2.25 \\
\hline $\mathrm{Biz}$ & 25.0 & 5.45 & 1.40 & 5.90 & 3.50 \\
\hline Enzyme and Biz & 20.0 & 3.75 & 1.25 & 2.95 & 2.75 \\
\hline
\end{tabular}

(ca. $240 \mathrm{mg} / \mathrm{l}$ oxygen). The BOD value of poultry waste, however, would be of little or no use if the droppings per se were dried. Such information would be useful were the droppings mixed with water, for ease of handling, disposal in a lagoon, oxidation ditch, or some other such disposal method.

The rate of drying poultry waste produced a uniform slope from moist condition to oven dry condition. The degree of slope varied according to the drying temperature. The higher the temperature the steeper the slope. The slopes resulting from drying temperatures $100^{\circ} \mathrm{C}, 85^{\circ} \mathrm{C}$, and $70^{\circ} \mathrm{C}$ were not too different one from another. However, the slopes resulting from drying temperatures of $55^{\circ} \mathrm{C}$ and $45^{\circ} \mathrm{C}$ were less steep than those of the higher temperatures.

Strong odors were given off during the drying of the waste at all temperatures. At $85^{\circ} \mathrm{C}$ and $100^{\circ} \mathrm{C}$ temperatures the odors were noticeable soon after placing the samples in the drying ovens but they seemed to be volatilized rather quickly. At $70^{\circ} \mathrm{C}, 55^{\circ} \mathrm{C}$, and $45^{\circ} \mathrm{C}$ the odor was slower to become apparent but continued over a much longer time than at the two higher temperatures.

The bacterial density of moist poultry waste is reduced about 99 per cent within the first two hours when exposed to $100^{\circ} \mathrm{C}$ temperature. This period corresponds to a considerable reduction in moisture. The data indicate that those organisms capable of surviving the first thirty minutes of drying stand a good change of surviving the drying period. This seems to be more true of the 
aerobes than of the anaerobes. Sussman and Halvorson (34) have shown that often lipids contribute to heat resistance but in our study we were not concerned with the "why" of resistance.

As the drying temperatures decreased the rate of bacterial dying became less and showed a trend of increased survival. This might be because of less intense moist heat during the initial heating period.

The fact that some bacteria survived in the poultry waste samples dried at $100^{\circ} \mathrm{C}$ for 8 hours is significant. These are representatives of bacteria which are not readily killed by conventional sterilization methods. Of those identified, the isolates of $B$. stearothermophilus and B. coagulans are commonly found in certain waste materials. Other isolates which were identified only as $\mathrm{H}_{2} \mathrm{~S}$ producers and nitrate reducers could possibly be important contributors to the cause of the foul odors of moist poultry waste after a few days.

There is a little offensive odor associated with poultry waste immediately after defecation. After dropping offensive odors increase with time. This odor increase apparently is associated with increased microbial activity metabolizing certain organic materials present to fatty acids and other foul smelling compounds.

The density trend of bacteria in stored poultry wastes might be of value in the determination of its fertilizer value. Because of maggot infestation density trends of aerobic and anaerobic uric acid decomposers and sulfate reducers were not determined after eight days storage. The formation of ammonia in poultry results, at least partially, from the aerobic and anaerobic breakdown of the uric acid. At defecation few of these organisms seem to be present and there is little ammonia odor. As the microorganisms increase the ammonia odor becomes more noticeable. Uric acid decomposers in the waste seem to reach their density peak after two days and then begin to decrease.

The numbers of sulfate reducing bacteria in the poultry waste remained more or less unchanged in storage for four days and then began to increase.

The use of bacterial enzyme concentrates in poultry manure disposal systems for odor control apparently has not been extensively studied. There do exist, however, a few detailed reports, some advocating and some against enzyme use. For this study investigations were concerned with the effect of enzymes on the $\mathrm{C}_{2}-\mathrm{C}_{6}$ fatty acids. These have disagreeable odors and were easily measured.

The results indicate that fatty acid content was reduced most significantly by heating at $45^{\circ} \mathrm{C}$ to dryness. Acetic, propionic, isobutyric, and butyric acids were reduced by one-half but isovaleric acid showed no effect from the heat. However, this would pose an additional problem of air pollution in a large-scale operation.

The $P$. vulgaris enzyme extract and the enzyme from Biz-chosen because it is used on related compounds in cleaning clothes (16)-appeared to be the most successful of those enzymes studied. However, their effect did not greatly 
decrease the fatty acid content below that resulting from heating alone. The possibility does exist that further purification of the extracted enzymes and combinations of the two with heat might lead to better results. Also, measurement of other odor-contributing compounds may indicate further possibilities for enzymes in odor control. The major drawback of using these additives would be economical in view of the limited success thus far demonstrated.

\section{SUMMARY}

The results of this investigation can be summarized as follows:

1. Bulk analysis showed poultry wastes averaged $24.76 \%$ solids, $75.23 \%$ moisture, $30.29 \%$ ash, and $69.71 \%$ volatile material.

2. Upon heating to dryness at $45^{\circ} \mathrm{C}$, wastes showed a $20.76 \%$ loss of nitrogen and $5.94 \%$ loss of phosphorus.

3. An average five-day BOD for poultry waste-slurry was $340 \mathrm{ppm} / \mathrm{l}$.

4. Complete drying determined on $25-\mathrm{g}$ waste samples required 8 hours $\left(100^{\circ} \mathrm{C}\right), 9$ hours $\left(85^{\circ} \mathrm{C}\right), 11$ hours $\left(70^{\circ} \mathrm{C}\right), 22$ hours $\left(55^{\circ} \mathrm{C}\right)$ and 30 hours $\left(45^{\circ} \mathrm{C}\right)$.

5. At $100^{\circ} \mathrm{C}$ for 8 hours and total dryness some sporeformers remained viable. Some of these isolates, by the odor produced in pure culture, would be important contributors to the offensive odor of poultry wastes.

6. At all temperatures studied $(100,85,70,55$, and $45 \mathrm{C})$ anaerobes, particularly anaerobic sporeformers, showed consistently less resistance to heat than the other groups being followed.

7. Drying alone reduced the quantity of acetic, propionic, isobutyric, and butyric acids in poultry wastes by approximately one-half. No reduction of iso-valeric acid.

8. Although the reduction was not as significant as heating alone, an enzyme extract from Proteus vulgaris and the enzyme concentrate Biz (commercially prepared enzyme detergent) combined with heating to dryness $\left(45^{\circ} \mathrm{C}\right)$ showed the greatest additional decrease in fatty acid content (beyond the heat reduction) in poultry waste of the enzyme preparations that were under consideration. Isovaleric acid also showed a decrease which was not demonstrated with heat alone. 


\section{LITERATURE CITED}

1. Bell, D. D., R. G. Curley, and E. C. Loomis. 1965. Poultry manure removal systems. U. of Cal. Agr. Expt. Sta. Ser. AXT 189.

2. Benham, C. L. 1967. The effectiveness of caustic soda in preventing the development of smell in poultry droppings slurry pits. Rept. from Nat. Agricultural Advisory Ser., Shardlow Hall, Shardlow, Darby, England.

3. Burnett, William E. 1969. Air pollution from animal wastes. Determination of malodors by gas chromatographic and organoleptic techniques. Environmental Sci. and Technology 3: 744-749.

4. Burnett, William E. 1969. Odor transport by particulate matter in high density poultry houses. Poultry Sci. 48(1): 182-185.

5. Burnett, W. E., and N. C. Dondero. 1968. The control of air pollution (odors) from animal wastes-evaluation of commercial odor control products by an organoleptic test. ASAD Paper No. 68-909.

6. Burnett, W. E., and N. C. Dondero. 1969. Microbiological and chemical changes in poultry manure associated with decomposition and odor generation. Presented at the Cornell Agr. Waste Managt. Conf. Hotel Syracuse, Syracuse, N.Y.

7. Burnett, W. E., and N. C. Dondero. 1969. Soil filtration to remove odors. From: Odors, gases and particualte matter from high density poultry management systems as they relate to air pollution. Cornell Univ. Rept., Ithaca, N.Y.

8. Burnett, W. E., and B. Gormel. 1969. Odor control by chemical treatment. From: Odors, gases and particualte matter from high density poultry management systems as they relate to air pollution. Cornell Univ. Rept., Ithaca, N.Y.

9. Cabes, Leon J., Jr., A. R. Colmer, H. T. Barr, and B. A. Tower. 1969. The bacterial population of an indoor poultry lagoon. Poultry Sci. 48(1): 54-63.

10. Deibel, R. H. 1967. Biological aspects of the animal waste disposal problem. 395-399. In: Nyle C. Brady (ed.), Agriculture and the quality of our environment. AAAS Pub. No. 85. Washington, D.C.

11. Faith, W. L. 1964. Odor control in cattle feedyards. J. Air Pollut. Control Assoc. 14(1): 459-460.

12. Hammond, W. D., D. L. Day, and F. L. Hansen. 1968. Can lime and chlorine suppress odors in liquid hog manure? Agr. Engr. 49(6): 340-343.

13. Hart, Samuel A. 1963. Fowl fecal facts. World Poultry Sci. J. 19: 262-272.

14. Hart, Samuel A. 1964. Thin spreading of slurried manures. Trans. of the ASAE 7: 22.

15. Hindin, E., D.S. May, R. McDonald, and S. H. Dunstan. 1964. Analysis of volatile fatty acids in sewage by gas chromatography. Water and Sewage Works 111: 92-95.

16. Hughes, Donald H. (Convener). 1971. Symposium: enzymes as additives in detergents. In: Proc. of the 27th Gen. Meeting of the Soc. for Indus. Micro. Vol. 12.

17. Johansson, K. R., W. B. Sailes, and S. K. Shapiro. 1948. The intestinal microflora of hens as influenced by various carbohydrates in a biotindeficient ration. J. Bact 0 56: 619-634.

18. Johnson, T. H., G. J. Mountney, and A. R. Winter. 1964. Treatment of poultry manure with bacteria and enzymes. Ohio Farm and Home Research 49: 26. Ohio Agr. Expt. Sta., Wooster.

19. Johnson, T. H., and G. J. Miountney. 1969. Poultry manure: production, utilization and disposal. World Poul. Sci. J. 25(3) : 202-217. 
20. Martin, W., E. V. Stratton, and L. Harwood. 1963. Poultry manure for fertilizer. Poultry Digest 22(254) : 28.

21. McKinney, R. E. 1962. Microbiology for sanitary engineers. McGraw-Hill Book Co., Inc., New York. p. 293.

22. Parker, C. A. 1955. Anaerobiases with iron wool. Australian J. Expt. Biol. 33: 33-38.

23. Pelczar, M. J., Jr. 1965. Laboratory exercises in microbiology. 2nd ed. McGraw-Hill Book Co. Inc., New York.

24. Postgate, J. 1963. Versatile medium for the enumeration of sulfate reducing bacteria. Appl. Micro. 11 : 265-267.

25. Robertson, L. S., and John Wolford. 1970. The effect of application rate of chicken manure on the yield of corn. Michigan State U. Agr. Expt. Sta. Res. Rept. No. 117. Michigan State Univ., East Lansing. pp. 10-15.

26. Schefferle, H. E. 1965. The decomposition of uric acid in built up poultry litter. J. Appl. Bact. 28(3): 412-420.

27. Schefferle, H. E. 1965. The microbiology of built up poultry litter. J. Appl. Bact. 28(3) : 403-411.

28. Schefferle, H. E. 1966. Coryneform bacteria in poultry deep litter. J. Appl. Bact. 29: 147-160.

29. Shannon, D. W. F., and W. O. Brown. 1969. Losses of energy and nitrogen on drying poultry excreta. Poultry Sci. 48(1): 41-43.

30. Smith, H. L., Jr., and K. Goodner. 1958. Detection of bacterial gelatinases by gelatin agar plate methods. J. Bact. 76(6): 662-665.

31. Sobel, A. T. 1966. Physical properties of animal manures associated with handling. Proc. of National Symposium on Management of Farm Animal Wastes, ASAE, St. Joseph, Mich., May, 1966.

32. Sobel, A. T. 1969. Removal of water from animal manures. Presented at the Animal Waste Management Conf., Hotel Syracuse, Syracuse, N.Y.

33. Standard methods for the examination of water, sewage and industrial waste. 1965. 12 ed. Am. Pub. Health Assoc., Inc., New York.

34. Sussman, A. G., and H. O. Halvorson. 1966. Spores, their dormancy and germination. Harper and Row, New York.

35. Taiganides, E. Paul, and Richard K. White. 1969. Controlling odors-mission impossible? Poultry Digest 28: 16-19.

36. Thompson, F. C. 1969. Microbiology and fatty acid production in sanitary landfills. Unpublished Master's Thesis. West Virginia Univ., Morgantown.

37. Winter, A. R. 1962. Chicken manure: good fertilizer. Ohio Farm and Home Res. 47(2): 29. Ohio Agr. Expt. Sta., Wooster.

38. Yushok, Wasley and Furman E. Bear. 1948. Poultry manure-its preservation, deodorization and disinfection. New Jersey Agr. Expt. Sta. Bull. No. 707. Rutgers Univ. New Brunswick. pp. 1-11. 
[Blank Page in Original Bulletin] 
[Blank Page in Original Bulletin] 
[Blank Page in Original Bulletin] 